Biol. Stud. 2010: 4(2); 159-170 • DOI: https://doi.org/10.30970/sbi.0402.127

www.http://publications.Inu.edu.ua/journals/index.php/biology

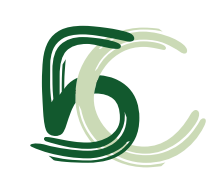

УДК 577.391:621.386.86

КАРОТИНОЇДИ: БУДОВА, ВЛАСТИВОСТІ ТА БІОЛОГІЧНА ДІЯ

М. Сімонова

Інститут біології тварин УААН, вул. В. Стуса, 38, Львів 79034, Україна

e-mail:inenbiol@mail.Iviv.ua

У статті розглядаються будова й антиоксидантні властивості молекул каротиноїдів у зв'язку з їхніми структурними особливостями. Наведено дані літератури про засвоєння каротиноїдів тваринами та локалізацію цих сполук у клітинах. Обговорюються деякі аспекти біологічної дії каротиноїдів. Показано, що антиканцерогенна активність цих сполук зумовлена їхнім впливом на вільнорадикальні реакції, стимулюванням імунної системи, здатністю регулювати міжклітинні контакти, індукувати апоптоз малігнізованих клітин.

Ключові слова: каротиноїди, антиоксиданти, антиканцерогенна дія.

Каротиноїди є найбільш розповсюдженою, численною та важливою групою природних пігментів. За хімічною будовою каротиноїди належать до класу терпенів, вони широко розповсюджені як у фотосинтезувальних, так і у нефотосинтезувальних організмах. Рослини, деякі бактерії та гриби синтезують каротиноїди de novo, а тварини і людина одержують їх із їжею $[1,2,7]$.

Молекули каротиноїдів містять вісім $\mathrm{C}_{5}$-ізопренових фррагментів і можуть на одному або обох кінцях закінчуватися циклогексеновим (іононовим) кільцем. Існують також каротиноїди з числом атомів вуглецю меншим за 40 (нор- і апокаротиноїди) і більшим (гомо-каротиноїди). Хромофорна група каротиноїдів представлена полієновим ланцюгом спряжених подвійних зв'язків, унаслідок чого вони поглинають світло у діапазоні 400-500 нм і мають жовте або оранжеве забарвлення. Каротиноїдні вуглеводні відомі під назвою каротинів (лікопін, $\beta$-каротин і його ізомери), а похідні з кисневмісними групами належать до групи ксантофрілів (лютеїн, зеаксантин, астаксантин, кантаксантин - див. рисунок). Каротиноїди в чистому вигляді характеризуються високою лабільністю, вони дуже чутливі до дії сонячного світла, кисню повітря, нагрівання, дії кислот і лугів. Під впливом цих фракторів вони окиснюються та руйнуються.

У живих організмах каротиноїди можуть перебувати в різних станах: вільному, у вигляді ефрірів жирних кислот і глікозидів, а також у каротинопротеїнових комплексах. Природа каротинопротеїнового зв'язку лишається нез'ясованою, показано лише, що у цій взаємодії ковалентні зв'язки участі не беруть [1, 10]. Наявність подвійних 
зв'язків, циклічних кілець і асиметричних атомів вуглецю зумовлює існування великої кількості стереоізомерів. У природі більшість каротиноїдів існує переважно у транс-фрормі [27, 81, 83].

I

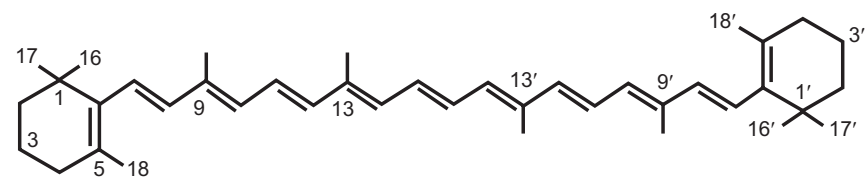

II<smiles>CC1=C(/C=C/C(C)=C/C=C/C=C/C=C/C=C/C=C/C=C/C=C/C=C(C)/C=C/C2=C(C)C(=O)C(O)CC2(C)C)C(C)(C)CC(O)C1=O</smiles>

III

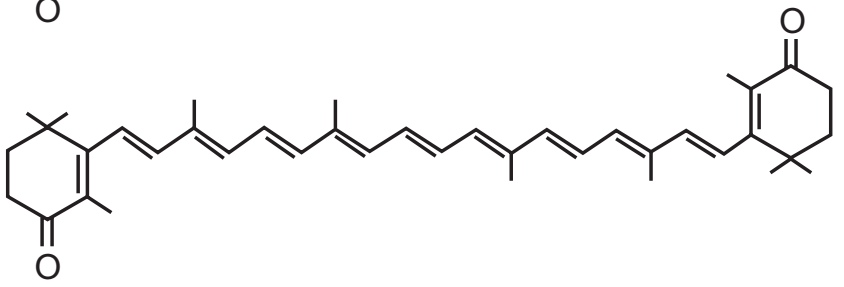

IV<smiles>CC1=C(/C=C/C(C)=C/C=C/C=C/C(C)=C/C=C/C(C)=C/C=C/C=C(C)/C=C/C2=C(C)CC(O)CC2(C)C)C(C)(C)CC(O)C1</smiles>

$\mathbf{V}$<smiles>CC(C)=CCC/C=C(\C)CCC/C=C(C)/C=C/C=C/C=C(C)/C=C/C=C/C=C(C)/C=C/C=C(C)/C=C/C=C(C)/C=C/C=C(\C)CCCC=C(C)C</smiles>

Структура каротиноїдів [3]: I - $\beta$-каротин; II - астаксантин; III - кантаксантин; IV - зеаксантин; $\mathrm{V}$ - лікопін

Structure of carotenoids [3]: I - $\beta$-carotene; II - astaxanthin; III - canthaxanthin; IV - zeaxanthin; $\mathrm{V}$ - lycopene

Ідентифіковано близько 600 різних каротиноїдів, із них тільки 10\% мають проA-вітамінну активність [71]. $\beta$-каротин і його ізомери, а також криптоксантин виявляють А-вітамінну дію. Оксикаротиноїди практично не утворюють вітаміну А [23]. Тривалий час існувала думка, що основна фрункція каротиноїдів в організмі тварин зумовлена перетворенням у вітамін А, який бере участь у фроторецепції, регуляції проліферації та диференціюванні клітин $[12,89]$. Термін „вітамін А” охоплює родину ретиноїдів, куди входить ретинол і його природні метаболіти: ретиналь, ретиноєва кислота і велика кількість синтетичних аналогів. До теперішнього часу чітко встановлено, що, крім добре відомої ролі у забезпеченні процесів зору, вітамін А впливає на різні аспекти життєдіяльності організму: диференціацію та проліферацію клітин, на ріст і репродукцію, бере участь у процесі кровотворення, функціонуванні імунної системи $[7,12]$. Достатньо добре вивченою $є$ фрункція каротиноїдів 
як фоторецепторних молекул у фотосинтезувальних організмів і функція апокаротиноїдів в органах зору тварин [20, 36, 50, 93]. Одним із механізмів дії ретиноїдів $\epsilon$ активація деяких генів $[13,57,59]$. На даний час показано, що каротиноїди проявляють низку властивостей, які не пов'язані з А-вітамінною дією. Відомо, що каротиноїди підвищують резистентність організму до мутагенів і канцерогенів [9, 21], знижують вікові дегенеративні зміни у тканинах [36, 38, 92], інгібують проліферацію злоякісних клітин [46], активують синтез цитокінів та інтерлейкінів [15, 92], беруть участь у регуляції транскрипції генів [70], а також проявляють імуномодулюючу дію $[45,47]$.

Епідеміологічні дослідження показали, що зменшення споживання або засвоєння каротиноїдів підвищує ризик виникнення раку, катаракти, серцево-судинних та інших захворювань [22, 52, 91, 104].

Показано, що людина споживає з їжею близько 50 каротиноїдних сполук [51], 20 із них виявлені у плазмі крові та тканинах $[30,49]$. Значна частина каротиноїдів (20\% від загальної кількості) у сироватці крові людини ще не ідентифікована [14]. Вважають, що каротиноїди всмоктуються у тонкому кишечнику методом пасивної дифузії $[71,77]$. Невідомо, чи існують спеціальні механізми транспорту каротиноїдів крізь біологічні мембрани. Ступінь всмоктування залежить від низки факторів (наявності ліпідів і білків у раціоні, віку, гормонального статусу тварин та ін.) і зменшується при підвищенні вмісту каротиноїдів у раціоні $[77,78]$. Вміст $\beta$-каротину у плазмі крові, печінці та наднирниках знижується при додаванні до раціону лікопіну або кантаксантину, що, можливо, пов'язано з конкурентною абсорбцією [71].

Рівень каротиноїдів у крові залежить від їхнього рівня у їжі, а тому може значно коливатися. Так, вміст $\beta$-каротину в сироватці крові може становити від 5,1 до 52,9 мкг/100 мл, $\alpha$-каротину від 1,2 до 19,7 мкг/100 мл, а лікопіну - від 0 до 41,0 мкг/100 мл. Виявлено індивідуальні, вікові, статеві та регіональні відмінності щодо рівня каротиноїдів у плазмі крові людей $[14,71]$.

В експериментальних дослідженнях було показано, що при використанні препарату транс- $\beta$-каротину його концентрація у плазмі крові людей зростає в 4 рази, тоді як згодовування цис- $\beta$-каротину підвищує рівень каротиноїдів у крові лише на $10 \%$ [100]. Низька біологічна активність цис- $\beta$-каротину виявлена і в дослідах на щурах. На відміну від $\beta$-каротину, цис-фрорми лікопіну абсорбуються краще, ніж транс-ізомери [27]. У клітинах слизової оболонки кишечника людини може відбуватися ізомеризація 9-цис- $\beta$-каротину у транс-фрорму [100].

Абсорбований каротин в ентероцитах піддається окиснювальному розщепленню за участю $\beta$-каротин-15-15'-діоксигенази з утворенням ретиналю. Близько 80\% вітаміну А в організмі утворюється 3 -каротину. Активність $\beta$-каротин-15-15' діоксигенази виявлена у слизовій кишечника, легенях, нирках і клітинах мозку [97]. Швидкість і ступінь біоконверсії каротиноїдів регулюється активністю $\beta$-каротин- 15 15'-діоксигенази і клітинним ретинолзв'язуючим білком. Цей фрермент розщеплює каротиноїди, включаючи бета-апо-каротиналі, лише з утворенням ретиналю [66]. Активність $\beta$-каротин-15-15'-діоксигенази залежить від низки фракторів, зокрема, статусу вітаміну А в організмі, тому при споживанні високої дози каротиноїдів не спостерігається гіпервітамінозу A [7]. При дослідженні біодоступності кантаксантину і лікопіну в печінці щурів і мавп виявляли неметаболізовані каротиноїди, тоді як при споживанні $\beta$-каротину у клітинах нагромаджуються ретиналь, ретинол, апо-каротиноли з різною довжиною полієнового ланцюга, які утворюються в результаті нецентрального ензиматичного розриву молекули $[17,33]$. 
Існує видова специфрічність засвоєння каротиноїдів тваринами: ссавці краще засвоюють $\beta$-каротин, а риби і птахи - ксантофріли [7]. У лососевих риб оксикаротиноїди відкладаються в м'язах у вільному стані, а в шкірі - у вигляді ефрірів. У щурів, свиней, кіз, кролів і собак (так звані „біложирі” тварини) майже весь $\beta$-каротин після абсорбції ентероцитами перетворюється у вітамін А. У людини, великої рогатої худоби, птиці частина каротиноїдів не розщеплюється, а в інтактному вигляді транспортується лімфою, циркулює у зв'язаному вигляді з ліпопротеїдами плазми та депонується у тканинах [78].

Пік концентрації $\beta$-каротину у ліпопротеїдах лімфи з'являється через 4-6 год, а у плазмі крові - через 24 год після згодовування препарату цієї сполуки [71]. Полярні каротиноїди після споживання з'являються у крові значно швидше: у телят кантаксантин - через 9 год, у людей астаксантин - через $6,7 \pm 1,2$ год, а період $\tau 1 / 2$ елімінації з плазми становить $21,0 \pm 11,0$ год. У крові такі неполярні каротиноїди, як лікопін, $\beta$-каротин виявляють у ліпопротеїдах дуже низької щільності та низької щільності, а полярні (лютеїн, астаксантин) транспортуються ліпопротеїдами низької та високої щільності $[35,85]$. Механізми транспорту каротиноїдів із плазми крові у тканини вивчені мало. P. Bhosale et al. [20] виявили у мембранах сітківки ока людини ксантофрілзв'язуючий білок, який селективно зв'язує зеаксантин, але не лютеїн.

Каротиноїди виявлено в усіх органах і тканинах тварин, проте найбільше їх міститься у жировій тканині, печінці та наднирниках [78].

Гідрофробні властивості каротиноїдів зумовлюють їхню здатність вбудовуватися у мембрани. Молекули $\beta$-каротину та зеаксантину розміщуються всередині мембрани перпендикулярно до її площини, а у лютеїну частина молекули розміщена вертикально до мембрани, а друга частина молекули зігнута під прямим кутом і орієнтована паралельно до площини мембрани [84]. Розміщення молекул каротиноїдів перпендикулярно до площини мембрани створює можливість уловлювати вільні радикали подвійними зв'язками на різній глибині мембрани [24]. У дослідженнях на ліпосомах показано, що включення каротиноїдів у двошарову фосфоліпідну структуру впливає на впорядкованість залишків жирних кислот і приводить до зміни проникливості та плинності мембран, що може впливати на активність мембранних фрерментів і рецепторів $[44,94]$. У клітинах печінки щурів білковокаротиноїдний комплекс локалізований переважно у цитоплазматичній мембрані, мітохондріальній і лізосомальній фрракціях клітини, а в ядерній і мікросомальній фракціях виявлено лише слідові кількості каротиноїдів. У мітохондріях вміст $\beta$-каротину у внутрішній мембрані у 20 разів вищий, ніж у зовнішній, що, очевидно, пов'язано з його важливою функцією в цих органелах. У клітинах печінки курей найбільше $\beta$-каротину виявлено у фракції мітохондрій, астаксантин локалізується переважно у мікросомальній фракції (білизько 50\%) і лише 15\% - у мітохондріях [85].

Наявність полієнового ланцюга та делокалізованої п-електронної структури 3 низьким енергетичним рівнем триплетного збудженого стану визначають біологічні фрункції каротиноїдів, пов'язані з антиоксидантною дією [23, 90]. Енергетична характеристика молекулярної структури каротиноїдів робить можливою передачу збудженого неспареного е $~ 3{ }^{1} \mathrm{O}_{2}$ або пероксид радикалу на молекулу каротиноїдів [75]. При збільшенні довжини полієнового ланцюга зростає ступінь його стабілізації та зменшується енергія триплетного п-електронного стану, що приводить до підвищення імовірності перенесення неспареного е- на молекулу каротиноїдів, а, значить, до збільшення антиоксидантної активності [3]. На антиоксидантну активність

ISSN 1996-4536 • Біологічні Студії / Studia Biologica • 2010 • Том 4/№2 • С. 159-170 
впливає і наявність іононових кілець, які порушують єдність основної структури делокалізованих п-електронів. У зв'язку з цим лікопін, який має 11 подвійних зв'язків, але у вигляді планарної структури, має більш збалансовану п-електронну систему, що і визначає збільшення його антиоксидантної активності майже удвічі порівняно з $\beta$-каротином, у молекулі якого також $є 11$ подвійних зв'язків, але наявні два іононові кільця [17]. При модифікації кільцевих структур кето- і гідроксигрупами (лютеїн, астаксантин) стійкість т-електронної структури зростає за рахунок п-електронних орбіталей цих груп і відповідно зростає їхня антиоксидантна активність. У дослідженнях на мембранних моделях з індукованими процесами перекисного окиснення експериментально було підтверджено вплив структурних змін у молекулах ка-

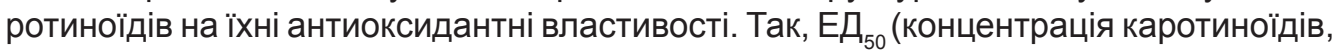
необхідна для інгібування процесів пероксидного окиснення ліпідів на 50\%) становила для $\beta$-каротину 960 нМ, для лютеїну, у молекулі якого є дві гідроксигрупи 700 нМ, а для астаксантину (дві кето- і дві гідроксигрупи) - 200 нМ [64]. M. Kurashige et al. [55] також наводять дані, які свідчать про те, що астаксантин ефрективніше, ніж $\beta$-каротин, захищає мітохондрії клітин печінки щура від ліпідної пероксидації. Вивчення активності різних антиоксидантів in vitro показало, що активності астаксантину, $\alpha$-токоферолу, $\alpha$-каротину, лютеїну, лікопіну, $\beta$-каротину, співвідносяться як 1,3:0,9:0,5:0,4:0,4:0,2 [67].

Взаємодія каротиноїдів з пероксидними радикалами, крім віддачі або приєднання електронів, може приводити до приєднання вільного радикала у місці подвійного зв'язку каротиноїдів (ROO + Кар $\rightarrow$ 'Кар-OOR), а також до перенесення атома водню від молекули каротиноїдів (ROO $\cdot$ + Кар $\rightarrow$ Kap $\left.{ }^{\bullet}+\mathrm{ROOH}\right)$. Напрям peакції пероксидних радикалів з каротиноїдами залежить від ряду фракторів: структури молекули каротиноїду, активності пероксидного радикала, а також оточення молекули каротиноїду $[48,58,60]$. Неполярний $\beta$-каротин і полярний зеаксантин в органічних розчинах проявляють майже однакові антиоксидантні властивості, проте при вбудовуванні у мембрану зеаксантин значно ефективніше нейтралізує вільні радикали, ніж $\beta$-каротин [96]. Дослідження механізмів антиоксидантної дії каротиноїдів показали, що їхня молекула може віддавати або приймати електрон від відповідних речовин з утворенням аніон- або катіон-радикалів [10]. При взаємодії з вільними радикалами каротиноїди можуть перетворюватися в перекиси, епоксиди, спирти, кетони і маловивчені полімери [33, 39, 48, 98]. При поглинанні синглетного кисню каротиноїди виділяють енергію у вигляді тепла і при цьому не потребують реакцій регенерації їхньої активної форми [29]. Однак біологічна дія каротиноїдів більшою мірою визначається хімічними реакціями, що спричиняють окиснення цих пігментів [24].

Аналіз механізмів дії каротиноїдів, природних і спеціально синтезованих для досліджень, показав, що швидкість захоплення пероксидного радикала молекулами каротиноїдів корелює з величиною їхнього потенціалу окиснення. $\beta$-каротин, для якого характерний найнижчий потенціал окиснення серед досліджуваних каротиноїдів, мав і найменшу швидкість захоплення пероксидних радикалів [10]. Слід відзначити, що в деяких дослідженнях була виявлена прооксидантна дія $\beta$-каротину [32, 40, 102, 103]. Встановлено, що $\beta$-каротин проявляє антиоксидантну дію тільки при малих концентраціях і при низькому тиску кисню, а при високих концентраціях він має прооксидантну активність [74]. Вважають, що за прооксидантну активність каротиноїдів відповідають нейтральні радикали Car та ROOCar, 
а також катіон-радикали $\mathrm{Car}^{+}$. Механізм прооксидантної дії полягає у взаємодії цих радикалів із молекулами кисню та в утворенні відповідних пероксидних радикалів [10]. У каротиноїдів, які містять оксигрупи, не виявлено прооксидантної активності $[24,60,63]$. Вважають, що таку відмінність у біологічній дії каротиноїдів зумовлює вплив оксигруп на структуру мембрани [63].

Одержані нами результати засвідчують, що згодовування каротиновмісних добавок щурам не тільки пригнічує вільнорадикальне окиснення біополімерів на початковій стадії, нейтралізуючи ініціатори цих процесів, але й може впливати на активацію ферментативної ланки системи антиоксидантного захисту, гальмуючи розвиток оксидативного стресу [5, 6, 11].

Антиоксидантні властивості каротиноїдів зумовлюють їхню фротозахисну, радіопротекторну, антимутагенну й антиканцерогенну дію. У живих організмах каротиноїди відіграють важливу роль у захисті тканин від ультрафіолетового опромінення $[8,56,70]$. Астаксантин проявляє сильніший захисний ефект від фоотооксидації, ніж лютеїн і каротин [69]. При радіо- та хіміотерапії знижується рівень $\beta$-каротину у плазмі крові $[28,65]$. Добавка $\beta$-каротину до раціону мишей підвищує виживання опромінених тварин на 30-ту добу з 30 до 70\% та збільшує середню тривалість життя [3]. Радіопротекторна дія виявлена і при дослідженні лікопіну, який виявився удвічі ефективнішим,ніж $\beta$-каротин [4]. Співвідношення радіозахисної дії лікопіну та $\beta$-каротину позитивно корелює з їхньою антиоксидантною активністю. Такі результати дали змогу авторам зробити припущення, що гальмування вільнорадикальних процесів відіграє основну роль у радіопротекторному ефекті каротиноїдів. Проте не виключено, що радіозахисні властивості каротиноїдів зумовлені і їхньою здатністю регулювати процеси розмноження, диференціювання та трансформацію клітин [3].

Численні дослідження демонструють антиканцерогенну дію каротиноїдів [16, $34,72,104]$. Каротиноїди знижують частоту індукованих пухлин сечового міхура [88], раку молочної залози [26], ротової порожнини [87], кишечника [86]. У численних епідеміологічних дослідженнях показано зниження ризику розвитку онкологічних захворювань при включенні у раціон каротиноїдів. Вважають, що антиканцерогенна дія $\beta$-каротину зумовлена ферментативним розщепленням до ретиноїдів [12]. Так, було доведено, що ретиноєва кислота спроможна викликати диференціацію клітин ембріональної карциноми і що під її впливом клітини змінюють свій злоякісний характер. Завдяки дослідженням різних наукових груп встановлено, що лейкемічні клітини можуть диференціюватися при додаванні невеликої концентрації ретиноєвої кислоти. Це відкриття привело до успішного використання трансретиноєвої кислоти як стимулюючого агента при лікуванні промієлоцитарної лейкемії людини $[42,68]$. Протягом останніх років з'явилися численні дослідження, присвячені з'ясуванню взаємодії вітаміну А та експресії певних генів. Низка вчених, незалежно один від одного, отримали дані, які дають можливість припустити, що механізм контролю транскрипції ретиноїдами аналогічний механізмові дії інших ліпофрільних гормонів - тиреоїдів і стероїдів [13, 57, 59].

Показано також, що ретиноєва кислота пригнічує активність теломерази у ракових клітинах [54, 79].

Каротиноїди, які не є попередниками вітаміну А, також впливають на ріст пухлин [68]. Кантаксантин у концентрації $10^{-4}-10^{-8} \mathrm{M}$ пригнічує проліферацію злоякісних клітин меланоми у мишей, але посилює ріст нетрансформованих клітин [41].

ISSN 1996-4536 • Біологічні Студії / Studia Biologica • 2010 • Том 4/№2 • С. 159-170 
Показано, що суміш продуктів окиснення лікопену індукує апоптоз у клітинах HL-60 промієлоцитарної лейкемії [68]. Пригнічувальний вплив кантаксантину на ріст пухлин також пояснюють індукцією апоптозу у малігнізованих клітинах [76]. Ці властивості не корелюють з антиоксидантними функціями каротиноїдів і спостерігаються у молекул, які не є попередниками вітаміну А [101]. Очевидно, антиканцерогенна дія каротиноїдів зумовлена впливом на вільнорадикальні реакції, які ушкоджують у клітинах молекули біополімерів [24, 80], стимулюванням імунної системи [25, 45, 46], індукцією синтезу ксенобіотикометаболізуючих фрерментів [31, 37, 43], а також здатністю регулювати міжклітинні контакти [18, 82, 95].

Як імуномодулятори каротиноїди активують синтез Т-залежних антитіл, цитокінів та інтерлейкінів, причому їхня дія проявляється на рівні регуляції транскрипції генів $[15,45,62]$. Під дією каротиноїдів змінюється співвідношення певних видів лімфоцитів: зростає кількість CD4-клітин, а також підвищується співвідношення CD4 /CD8 клітин. Астаксантин також може частково відновлювати знижену гуморальну імунну відповідь у старих мишей [47].

Антиканцерогенна дія каротиноїдів тісно пов'язана зі здатністю регулювати міжклітинні контакти трансформованих клітин $[87,95]$. Встановлено, що каротиноїди збільшують синтез і-РНК, яка кодує синтез коннексину-43 - білка, що бере участь у взаємодії клітин через міжклітинні щілинні контакти [53, 95].

Проте у деяких роботах показано, що споживання каротиноїдів може підвищувати ймовірність виникнення злоякісних пухлин. Автори пояснюють це прооксидантною дією цих сполук [19, 40, 73].

Аналіз даних літератури показує, наскільки складні та різноманітні прояви біологічної дії каротиноїдів у живих організмах. Численні експериментальні результати свідчать про те, що каротиноїди є надзвичайно важливою ланкою регуляції вільнорадикальних процесів у клітинах. Проте їхні механізми дії складні та з'ясовані недостатньо, що зумовлює актуальність експериментальних досліджень у цьому напрямі.

1. Бриттон Г. Биохимия природных пигментов. М.: Мир, 1986. $121 \mathrm{c.}$

2. Влізло В. В., Куртяк Б. М., Янович В. Г. та ін. Біохімічні основи нормування вітамінного живлення корів. 1. Жиророзчинні вітаміни. Біол. тварин, 2007; 7(1-2): 25-42.

3. Капитонов А. Б. Каротиноиды как антиоксидантные модуляторы клеточного метаболизма. Усп. совр. биол, 1996; 116 (2): 179-193.

4. Капитонов А.Б., Пименов А.М., Обухова Л.К. и др. Радиозащитная эффективность ликопина. Радиационная биол. Радиоэкология, 1994; 34 (3): 67.

5. Колісник М. І., Борецька Н. І., Камінська М. В. Вплив біомаси каротиносинтезуючих дріжджів Phaffia rhodozyma на стан антиоксидантної системи печінки при інтоксикації щурів тетрахлоретаном. Мед. хімія, 2007; 9 (3): 37-40.

6. Колісник М. І., Борецька Н. І., Сологуб Л. І. Стан вільнорадикального окиснення і антиоксидантної системи захисту у щурів при згодовуванні дріжджів Phaffia rhodozyma. Біол. тварин, 2007; 9 (1-2): 203-207.

7. Куртяк Б.М., Янович В.Г. Жиророзчинні вітаміни у ветеринарній медицині і тваринництві. Львів: Тріада плюс, 2004. 426 с.

8. Ладыгин В. Г., Гордеева С. В. Состав и спектральные свойства пигмент-белковых комплексов фотосистем I и II в клетках мутанта C-41 Chlamydomonas reinhardtii, не содержащего а-каротиноидов. Вестн. Башкир. ун-та, 2001; 2: 53-56.

9. Ляхович В. В., Вавилин В. А., Зенков Н. К. Активная защита при окислительном стрессе. Антиоксидант-респонсивный элемент. Биохимия, 2006; 71 (9): 1183-1197. 
10. Поляков Н. Э., Лешина Т. В. Некоторые аспекты реакционной способности каротиноидов. Окислительно-восстановительные процессы и комплексообразование. Успехи химии, 2006; 75(12): 1175-1192.

11. Сімонова М. І., Борецька Н. І., Камінська М. В. та ін. Дія $\beta$-каротину та каротинсинтезуючих дріжджів Phaffia rhodozyma на оксидативний стрес у щурів, інтоксикованих тетрахлоретаном. Укр. біохім. журн, 2010; 82 (3): 6-13.

12. Четыркин С. В. Транспорт и метаболизм витамина А. Укр. біохім. журн, 2000; 72. (3): 12-24.

13. Четыркин С. В., Чернухина Л. А, Донченко Г. В. Транспорт ретинола в клеточное ядро in vitro. Укр. биохим. журн, 1998; 70(2): 17-21.

14. Шашкина М. Я., Шашкин П. Н., Сергеев А. В. Биодоступность каротиноидов. Вопросы мед. химии, 1999; 45(2): http://medi.ru/pbmc/88902.htm

15. Abdel-Fatth G., Watzl B., Huang D. et al. Carotene in vitro stimulates tumour necrosis factor alpha and interleukin I alpha secretion by human pheripheral blood. Pergamon Press, 1993; 13(8): 863-871.

16. Bairati I., Meyer F., Gelinas M. et al. Randomized trial of antioxidant vitamins to prevent acute adverse effects of radiation therapy in head and neck cancer patients. J. Clin. Oncol, 2005; 23: 5805-5813.

17. Beom V., Bitsch R. Intestinal absorption of lycopene from different matrices and interactions to other carotenoids, the lipid status, and the antioxidant capacity of human plasma. Eur. J. Nutr, 1999; 69(3): 118-125.

18. Bertram J. S. Induction of connexin 43 by carotenoids: functional consequences. Arch. Biochem. Biophys, 2004; 430(1): 120-126.

19. Bertram S. J., Pung A., Churley M. et al. Diverse carotenoids protect against chemically induced neoplastic transformation. Carcinogenesis, 1991; 12(4): 671-678.

20. Bhosale P., Larson A. J., Frederick J. M. et al. Identification and characterization of a Pi isoform of glutathione S-transferase (GSTP1) as a zeaxanthin-binding protein in the macula of the human eye. J. Biol. Chem, 2004; 279(47): 49447-49454.

21. Bianchi L., Tateo F., Pizzala R. Carotenoids reduce the chromosomal damage induced by bleomycin in human cultured lymphocytes. Anticancer Res, 1993; 13(4): 1007-1010.

22. Blumberg J., Block G. The $\alpha$-Tocopherol, $\beta$-Carotene Cancer Prevention Study in Finland. Nutr. Rev, 1994; 52(7): 242-245.

23. Burton G. W. Antioxidant action of carotenoids. J. Nutr, 1989; 119(1): 109-111.

24. Burton G. W., Ingold K. U. $\beta$-Carotene: an usual type of lipid antioxidant. Science, 1984; 244: 569-573.

25. Chew B. P., Park J. S. Carotenoid action on the immune response. J. Nutr, 2004; 134(1): 257S-261S.

26. Chew B. P., Park J. S., Wong M. W. et al. A comparison of the anticancer activities of dietary $\beta$-carotene, canthaxanthin and astaxanthin in mice in vivo. Anticancer Res, 1999; 19(3a): $1849-1854$.

27. Clinton S. K., Emenhiser C., Schwartz S. J. et al. Cis-trans lycopene isomers, carotenoids, and retinol in the human prostate. Cancer Epidemiol. Biomarkers Prev., 1996; 5(10): 823-833.

28. Conklin K. A. Dietary Antioxidants During Cancer Chemotherapy: Impact on Chemotherapeutic Effectiveness and Development of Side Effects. Nutr. and Cancer, 2000; 37 (1): $1-18$.

29. Conn P. F., Schalch W., Truscott T. G. The singlet oxygen and carotenoid interaction. J. Photochem. Photobiol. B: Biol, 1991; 11(1): 41-47.

30. Crews H., Alink G., Andersen R. A critical assessment of some biomarker approaches linked with dietary intake. Br. J. Nutr, 2001; 86(1): 5-35.

31. Cunningham F. X., Gantt E. Genes and enzymes of carotenoid biosynthesis in plants. Annu. Rev. Plant Pysiol. Plant Mol. Biol, 1998. 49: 557-583.

32. El-Agamey A., Lowe G. M., McGarvey D. J. et al. Carotenoid radical chemistry and antioxidant/pro-oxidant properties. Arch. Biochem. Biophys, 2004; 430(1): 37-38.

ISSN 1996-4536 • Біологічні Студії / Studia Biologica • 2010 • Том 4/№2 • С. 159-170 
33. Ferreira A. L., Yeum K. J., Russell R. M. et al. Enzymatic and oxidative metabolites of lycopene. J. Nutr. Biochem, 2004: 15(8): 493-502.

34. Flagg E. W., Coates R. J., Greenberg R. S. Epidemiologic studies of antioxidants and cancer in humans. J. Am. Coll. Nutr, 1995; 14(5): 419-427.

35. Furr H. C., Clark R.M. Intestinal absorption and tissue distribution of carotenoids. Nutr. Biochem, 1997; 8(5): 364-377.

36. Gerster H. Review: antioxidant protection of the ageing macula. Age Ageing, 1991; 20(1): 60-69.

37. Gradelet S., Astorg P., Leclerc J. et al. Effects of canthaxanthin, astaxanthin, lycopene and lutein on liver xenobioticmetabolizing enzymes in the rat. Xenobiotica, 1996; 26 (1): 49-63.

38. Gross M. D., Snowdon A. D. Plasma lycopene and longevity: Findings from the Nun Study. FASEB J, 2001; 15(4): 400.

39. Handelman G. J., Kuijk F. J., Chatterjee A. et al. Characterization of products formed during the autoxidation of $\beta$-carotene. Free Rad. Biol. Med, 1991; 10(6): 427-437.

40. Hennekens C. H., Buring J. E., Manson J. E. et al. Lack of effect of long-term supplementation with $\beta$-carotene on the incidence of malignant neoplasms and cardiovascular disease. N. Engl. J. Med, 1996; 334(18): 1145-1149.

41. Huang D. S., Odeleye O. E., Watson R. R. Inhibitory effects of canthaxanthin on in vitro growth of murine tumour cells. Cancer Lett, 1992; 65 (3): 209-213.

42. Huang M.E., Ye Y., Chen S.R. et al. Use of all-trans-retinoic acid in treatment of acute promyelocytic leukemia. Blood, 1988; 72(2): 267-272.

43. Jewell C., O'Brien N. Effect of dietary supplementation with carotenoids on xenobiotic metabolizing enzymes in the liver, lung, kidney and small intestine of the rat. Br. J. Nutr, 1999; 81(3): 235-242.

44. Jezowska I., Wolak A., Gruszecki W. et al. Effect of $\beta$-carotene on structural and dynamic properties of model phosphatidylcholine membranes. II. A ${ }^{31} \mathrm{P}-\mathrm{NMR}$ and ${ }^{13} \mathrm{C}-\mathrm{NMR}$ study. Biochim. Biophys. Acta, 1994; 1194 (1): 143-148.

45. Jyonouchi H., Hill R. J., Tomita Y. et al. Studies of immunomodulating actions of carotenoids. I. Effects of $\beta$-carotene and astaxanthin on murine lymphocyte functions and cell surface marker expression in in vitro culture system. Nutr. Cancer, 1991; 16(1): 93-105.

46. Jyonouchi H., Sun S., lijima K. et al. Antitumor activity of astaxanthin and its mode of action. Nutr. Cancer, 2000; 36(1): 59-65.

47. Jyonouchi H., Zhang L., Gross M. et al. Immunomodulating actions of carotenoids: Enhancement of in vivo and in vitro antibody production to Tdependent antigens. Nutr. Cancer, 1994; 21(1): 47-58.

48. Kennedy T. A., Liebler D. C. Peroxyl radical oxidation of $\beta$-carotene: formation of $\beta$-carotene epoxides. Chem. Res. Toxicol, 1991; 4(1): 290-295.

49. Khachik F., Spangler C. J., Smith J. C. et al. Identification, quantification, and relative concentrations of carotenoids and their metabolites in human milk and serum. Anal. Chem, 1997; 69(9): 1873-1881.

50. Kowluru R. A., Menon N. B., Gierhart D. L. Beneficial Effect of Zeaxanthin on Retinal Metabolic Abnormalities in Diabetic Rats. Investigative Ophthalmology and Visual Science, 2008; 49 (4): 1645-1651.

51. Krinsky N. I. Actions of carotenoids in biological systems. Ann. Rev. Nutr, 1993; 13: 561-587.

52. Krinsky N. I., Johnson E.J. Carotenoid actions and their relation to health and disease. Mol. Aspects Med, 2005; 26(6): 459-516.

53. Krutovskikh V., Asamoto M., Takasuka N. et al. Differential dose-dependent effects of alpha-, $\beta$-carotenes and lycopene on gap-junctional intercellular communication in rat liver in vivo. Jpn. J. Cancer Res, 1997; 88(12): 1121-1124.

54. Kunisada M., Budiyanto A., Bito T. et al. Retinoic acid suppresses telomerase activity in HSC-1 human cutaneous squamous cell carcinoma. Br. J. Dermatol, 2005; 152(3): 435443. 
55. Kurashige M., Okimasu E., Inoue M. et al. Inhibition of oxidative injury of biological membranes by astaxanthin. Physiol. Chem. Phys. Med, 1990; 22(1): 27-38.

56. Lee J., Jiang S., Levine N. et al. Carotenoid supplementation reduces erythema in human skin after simulated solar radiation exposure. Proc. Soc. Exp. Biol. and Med, 2000; 223(2): 170-174.

57. Levin A.A. 9-cis retinoic acid stereoisomer binds and activates the nuclear receptor RXR $\alpha$. Nature, 1992; 355: 359.

58. Liebler D. C., McClure T. D. Antioxidant reactions of $\beta$-carotene: Identification of carotenoidradical adducts. Chem. Res. Toxicol, 1996: 9(1): 8-11.

59. Mangelsdorf D.J., Thummel C., Beato $M$. et al. The nuclear receptor superfamily: the second decade. Cell, 1995: 83(6): 835-839.

60. Martin H. D., Ruck C., Schmidt M. Chemistry of carotenoid oxidation and free radical reactions. Pure Appl. Chem, 1999; 71(12): 2253-2262.

61. Mattel M.G., Petkovich M., Mattel J. F. et al. Mapping of the human retinoic acid receptor to the q21 band of chromosome 17. Hum. Genet, 1988; 80: 186-188.

62. McDevitt T. M., Tchao R., Harrison E. H. et al. Carotenoids normally present in serum inhibit proliferation and induce differentiation of a human monocyte/macrophage cell line (U937). J. Nutr, 2005; 135(2): 160-164.

63. McNulty H. P., Byun J., Lockwood S. F. et al. Differential effects of carotenoids on lipid peroxidation due to membrane interactions: X-ray diffraction analysis. Biochim. Biophys. Acta, 2007; 1768(1): 167-174.

64. Miki W. Biological function and activities of animal carotenoids. Pure Appl. Chem, 1991; 63(1): 141-146.

65. Moss R. W. Should Patients Undergoing Chemotherapy and Radiotherapy Be Prescribed Antioxidants? Integrative Cancer Therapies, 2006; 5(1): 63-82.

66. Nagao A. Oxidative Conversion of Carotenoids to Retinoids and Other Products. J. Nutr, 2004; 134(1): 237S-240S.

67. Naguib M. A. Antioxidant activities of astaxanthin and related carotenoids. J. Agric. Food Chem, 2000; 48(4): 1150-1154.

68. Nara E., Hayashi H., Kotake $M$. et al. Acyclic carotenoids and their oxidation mixture inhibit the growth of HL-60 human promyelocytic leukemia cells. Nutr. Cancer, 2001; 39(4): 273-283.

69. O'Connor N., O'Brien I. Modulation of UVA light-induced oxidative stress by $\beta$-carotene, lutein and astaxanthin in cultured fibroblasts. J. Dermatol. Sci, 1998; 16: 226-230.

70. Obermuller-Jevic U. C., Obermuller-Jevic U. C., Francz P. I. Enhancement of the UVA induction of haem oxygenase-1 expression by $\beta$-carotene in human skin fibroblast. FEBS Lett, 1999; 460 (2): 212-216.

71. Olson J. A. Absorption, transport, and metabolism of carotenoids in humans. Pure \&Appl. Chem, 1994; 66(5): 1011-1016.

72. Olson J. A. Carotenoids, vitamin A and cancer. J. Nutr, 1986; 116(6): 1127-1130.

73. Omenn G. S., Goodman G. E., Thornquist. D. M. et al. Risk factors for lung cancer and for intervention effects in CARET, the $\beta$-Carotene and Retinol Efficacy Trial. J. Natl Cancer Inst, 1996; 88(21): 1550-1559.

74. Palozza P. Prooxidant actions of carotenoids in biologic systems. Nutr. Rev, 1998; 56(9): 257-265.

75. Palozza P., Krinsky N. I. Antioxidant effects of carotenoids in vitro and in vivo: an overview. Methods Enzymol, 1992; 213: 403-420.

76. Palozza P., Maggiano N., Calviello G. Canthaxanthin induces apoptosis in human cancer cell lines. Carcinogenesis, 1998; 19(2): 373-376.

77. Parker R. S. Absorbtion, metabolism, and transport of carotenoids. FASEB J, 1996; 10(5): 542-551.

78. Parker R. S. Carotenoids in Human Blood and Tissues. J. Nutr, 1989; 119(1): 101-104.

79. Purev E., Soprano D. R., Soprano K. J. Effect of all-trans retinoic acid on telomerase activity in ovarian cancer cells. J. Exp. Clin. Cancer Res, 2004; 23(2): 309-316.

ISSN 1996-4536 • Біологічні Студії / Studia Biologica • 2010 • Том 4/№2 • С. 159-170 
80. Rousseau E. J., Davison A. J., Dunn B. Protection by $\beta$-carotene and related compounds against oxygen-mediated cytotoxicity and genotoxicity: implications for carcinogenesis and anticarcinogenesis. Free Rad. Biol. Med, 1992; 13(4): 407-433.

81. Shaish A., Avron M., Ben-Amotz A. Effect of inhibitors on the formation of stereoisomers in the biosinthesis of $\beta$-carotene in Dunaliella bardawil. Plant. Cell. Physiol, 1990; 31(5): 689_ 696.

82. Stahl W., Nicolai S., Briviba K. et al. Biological activities of natural and synthetic carotenoids: induction of gap junctional communication and singlet oxygen quenching. Carcinogenesis, 1997; 18(1): 89-92.

83. Stahl W., Schwarz W., Sundquist A. R. et al. Cis-trans isomers of lycopene and $\beta$-carotene in human serum and tissues. Arch. Biochem. Biophys, 1992; 294(1): 173-177.

84. Sujak A., Okulski W., Gruszecki W. I. Organisation of xanthophyll pigments lutein and zeaxanthin and in lipid membranes formed with dipalmitoylphosphatidyl-choline. Biochim. Biophys. Acta, 2000; 1509(1): 255-263.

85. Takahashi K., Watanabe M., Takimoto T. et al. Uptake and distribution of astaxanthin in several tissues. and plasma lipoproteins in male broiler chickens fed a yeast (Phaffia rhodozyma) with a high concentration of astaxanthin. Br. Poult. Sci, 2004; 45(1): 133-138.

86. Tanaka T., Kawamori T., Ohnishi M. et al. Suppression of azomethane-induced rat colon carcinogenesis by dietary administration of naturally occurring xanthophylls astaxanthin and canthaxanthin during the postinitiation phase. Carcinogenesis, 1995; 16(12): 2957-2963.

87. Tanaka T., Makita H., Ohnishi M. et al. Chemoprevention of rat oral carcinogenesis by naturally occurring xanthophylls, astaxanthin and canthaxanthin. Cancer Res, 1995; 55(9): 4059-4064.

88. Tanaka T., Morishita Y., Suzui M. et al. Chemoprevention of mouse urinary bladder carcinogenesis by the naturally occurring carotenoid astaxanthin. Carcinogenesis, 1994; 15(1): P. 15-19.

89. Tapiero H., Townsend D. M., Tew K. D. The role of carotenoids in the prevention of human pathologies. Biomed. Pharmacother, 2004; 58(1): 100-110.

90. Tsuchihashi H., Kigoshi M., Iwatsuku M. et al. Action of $\beta$-carotene as an antioxidant against lipid peroxidation. Arch. Biochem. Biophys, 1995; 323(1): 137-147.

91. Voutilainen S., Nurmi T., Mursu J. et al. Carotenoids and cardiovascular health. Am. J. Clin. Nutr, 2006; 83(6): 1265-1271.

92. Wang J. Y., Wen L. L., Huang Y. N. et al. Dual effects of antioxidants in neurodegeneration: direct neuroprotection against oxidative stress and indirect protection via suppression of glia-mediated inflammation. Curr. Pharm. Des, 2006; 12(27): 3521-3533.

93. Warner K., Frankel E. N. Effects of $\beta$-carotene on light stability of soybean oil. J. Am. Oil Chem. Soc, 1987; 64(3): 213-218.

94. Wisniewska A., Widomska J., Subczynski W. K. Carotenoid-membrane interactions in liposomes: effect of dipolar, monopolar, and nonpolar carotenoids. Acta biochim. polonica, 2006; 53(3): 475-484.

95. Wolf $\mathrm{G}$. Retinoids and carotenoids as inhibitors of carcinogenesis and inducers of cell-cell communication. Nutr. Rev, 1992; 50: 270-274.

96. Woodall A. A., Britton G., Jackson M. J.. Carotenoids and protection of phospholipids in solution or in liposomes against oxidation by peroxyl radicals: relationship between carotenoid structure and protective ability. Biochim. Biophys. Acta, 1997; 1336(6): 575-586.

97. Wyss A.,. Wirtz G. M, Woggon W. D. et al. Expression pattern and localization of $\beta, \beta$-carotene 15,15'-dioxygenase in different tissues. Biochem J, 2001; 354(3): 521-529.

98. Yamauchi R., Miyake N., Inoue $H$. et al. Products formed by peroxyl radical oxidation of $\beta$-carotene. J. Agric. Food Chem, 1993; 41(2): 708-713.

99. Yeh S. L., Hu M. L Induction of oxidative DNA damage in human foreskin fibroblast Hs68 cells by oxidized $\beta$-Carotene and lycopene. Free Radic. Res, 2001; 35(2): 203-213.

100. You C. S., Parker R. S., Goodman K. J. et al. Evidence of cis-trans isomerization of 9 -cis- $\beta$ carotene during absorption in humans. Am. J. Clin. Nutr, 1996; 64(2): 177-183. 
101. Zhang L. X., Cooney R. V., Bertram J. S. Carotenoids up-regulate connexin43 gene expression independent of their provitamin A or antioxidant properties. Cancer Res, 1992; 52(20): 5707-5712.

102. Zhang P., Omaye S. T. Antioxidant and prooxidant roles for $\beta$-carotene, $\alpha$-tocopherol and ascorbic acid in human lung cells in vitro. Toxicol, 2001; 15 (1): 13-24.

103. Zhang P., Omaye S. T. $\beta$-carotene and protein oxidation effect of ascorbic and $\alpha$-tocopherol. Toxicol, 2000; 146(1): 37-47.

104. Ziegler R. G. A review of epidemiologic evidence that carotenoids reduce the risk of cancer. J. Nutr, 1989; 119(1): 116-122.

\section{CAROTENOIDS, THEIR STRUCTURE, PROPERTIES AND BIOLOGICAL ACTION}

\section{Simonova}

Institute of Animal Biology of UAAS, 38, Stoos St., Lviv 79034, Ukraine

Dependence of antioxidant properties upon structural features of carotenoids and structure of carotenoids itself are reviewed in this paper. Literature data concerning assimilation and accumulation of these substances in cell generalized in the article. Some aspects of biological effect of carotenoids are discussed as well. It has been shown that anticancerous activity of these substances is caused by their influence on free radical reaction, stimulating of immune system, ability to regulate intercellular connections and to induce apoptosis in malignisated cells.

Key words: carotenoids, antioxidants, anticancer activity.

\section{КАРОТИНОИДЫ, ИХ СТРУКТУРА, СВОЙСТВА И БИОЛОГИЧЕСКОЕ ДЕЙСТВИЕ}

\section{М. Симонова}

Институт биологии животных УААН, ул. В. Стуса, 38, Львов 79034, Украина

В статье рассматриваются строение и антиоксидантные свойства молекул каротиноидов в связи с их структурными особенностями. Приведены данные литературы об усвоении каротиноидов животными и локализации этих соединений в клетках. Обсуждаются некоторые аспекты биологического действия каротиноидов. Показано, что антиканцерогенная активность каротиноидов обусловлена их влиянием на свободнорадикальные реакции, стимулированием иммунной системы, возможностью регулировать межклеточные контакты, индуцировать апоптоз у малигнизированных клеток.

Ключевые слова: каротиноиды, антиоксиданты, антиканцерогенное действие.

Одержано: 13.09.2010

ISSN 1996-4536 • Біологічні Студії / Studia Biologica • 2010 • Том 4/№2 • С. 159-170 